\title{
Effect of Temperature on Dehydration Kinetics of Pre-Treated and Untreated Yam (Dioscorea spp) Slices
}

\author{
Egbe $\mathrm{EW}^{1 *}$
}

${ }^{1}$ Department of Agricultural and Environmental Engineering, PMB 071, Niger Delta University Wilberforce Island Amassom Bayelsa State, Nigeria

\author{
DOI: $\underline{10.36348 / \text { sjet.2022.v07i01.001 }}$ \\ | Received: 27.11.2021 | Accepted: 02.01.2022 | Published: 07.01.2022 \\ *Corresponding author: Egbe EW \\ Department of Agricultural and Environmental Engineering, PMB 071, Niger Delta University Wilberforce Island Amassom Bayelsa \\ State, Nigeria
}

\section{Abstract}

Yams (Dioscorea spp) are herbaceous vines which are cultivated for the consumption of their starchy tubers. And can be consumed either boiled or fried. Drying is a veritable technology for storage beyond immediate consumption. This study thus, investigated the drying rate and the best suitable model of yam slices of different thicknesses $(1.0 \mathrm{~mm}, 1.5 \mathrm{~mm}$ and $2.0 \mathrm{~mm}$ ) in thin layer using a laboratory convective oven dryer. A temperature range of $60-80^{\circ} \mathrm{C}$ in multiples of $10^{\circ} \mathrm{C}$ was selected and applied. Results were fitted to three thin-layer models of Page, Henderson and Lewis, and parameters $\left(\mathrm{R}^{2}\right.$, RMSE, $\mathrm{X}^{2}$ ) to select the suitable estimating thin-layer model. $\mathrm{R}^{2}$ values ranged from $0.912090-0.984462$ (pre-treated) and $0.947496-0.982675$ (untreated) for Lewis model; $0.996625-0.998228$ (pre-treated) and $0.994750-0.998897$ (untreated) for Henderson model; 0.940210 - 0.997329 (pre-treated) and 0.938921-0.995356 (untreated) for page model with rather low RMSE values ranging from0.031620-0.016657(pre-treated) and 0.030334-0.017589 (untreated) for Lewis model; 0.00773 - 0.005247 (pre-treated) and 0.009682-0.004439 (untreated) for Henderson model; 0.032675-0.006907 (pre-treated) and 0.033026-0.009107(untreated) for page model over the range of drying temperatures applied. The respective $X^{2}$ values ranging from $0.0000204300-0.0011310990$ (approximately $=0$ ), therefore, from the statistical analysis the Henderson model showed a reliable prediction of the drying kinetics of the yam slices at the chosen temperatures. Drying rate along with characterizing drying constant also increased exponentially with temperature. From observation, pre-treated yam slices dried faster than untreated yam slices.

Keywords: Yam, thin-layer models, slices thickness, drying curves, drying rate, moisture ratio, drying kinetics.

Copyright $\odot 2022$ The Author(s): This is an open-access article distributed under the terms of the Creative Commons Attribution 4.0 International License (CC BY-NC 4.0) which permits unrestricted use, distribution, and reproduction in any medium for non-commercial use provided the original author and source are credited.

\section{INTRODUCTION}

Yam (Dioscorea spp) is basically seasonal and becomes expensive at the time of scarcity. Despite the high level of scarcity, demand is still high therefore these crops are needed all year round. Yam (Dioscorea spp) tends to deteriorate in value thereby depreciating the market value of that product and at such preservation is required.

Yam (Dioscorea spp) is the common name for some plant species in the genus dioscorea (family dioscoreaceae) that form edible tubers. Yams are herbaceous vines that can live for more than two years which are cultivated for the consumption of their starchy tubers in many temperate and tropical regions, especially in Africa, South America and the Caribbean,
Asia and Oceania. The tubers themselves, also called yams vary in form (centre for agriculture and biosciences international, 2016).

Yam crops begin when whole seed tubers or portions are planted into mounds or ridges. The crop yield depends on how and where the sets are planted, sizes of mounds, interplant spacing, provision of stakes for the resultant plants, yam species and tuber sizes desired at harvest. Yam crops face pressure from a range of Insect pests and fungal and viral diseases as well as nematodes (calverly, 1998).

Dehydration is simply the significant loss of body fluid that impairs normal bodily function. It is a classical and complex processing technique employing simultaneous heat and mass transfer to get solid food 
products with extended shelf life. Data of moisture loss with respect to time and temperature has been found important to describe the inherent phenomenon during the drying kinetics study. Dehydration as a multifaceted unit operation involves moisture exchange through molecular or surface diffusion and capillary, hydrodynamic flow (sharma and Prasad 2001). Drying is a method used in food products, and it offers benefits not only as a method of preservation, but also reduces packaging and transportation costs by reducing weight and volume (A Dominoguez, 2020).

In drying, the removal of moisture prevents growth and reproduction of decay-causing microorganisms and minimizes many of the moisture driven deterioration reactions, targeting the retention of the function quality of bio-products (Vijaya and Orsat, 2007).

High moisture content in food products increases the activities of micro-organisms, chemical and biochemical reactions. Due to the high moisture content $(50-80 \%)$ wet basis of yam and its susceptibility to deterioration during storage, it is difficult to store fresh yams. Drying has been regarded by humans as probably the most important and oldest food preservation method and it entails a complex Thermal process in which simultaneous heat and mass transfer occur. It is a process of moisture reduction in agricultural products to extend its shelf life (Ojediran, 2020).

In this part of Africa (Nigeria), Dioscorea spp can be locally prepared in different ways into different delicacies such as pottage, yam pepper soup, can also be fried, etc. Dried white yam can be stored for a longer period, used as instant yam flour, cooking and extraction of resistant starch (Ojediran, 2020).

The study is to investigate the effects of temperature on the dehydration kinetics of pre-treated and untreated yam slices with respect to time (30 minutes intervals), at a varying temperature 60, 70 and $80^{\circ} \mathrm{C}$ with thicknesses of $1.0 \mathrm{~mm}, 1.5 \mathrm{~mm}$ and $2.0 \mathrm{~mm}$ using the oven drying method. Data obtained from the drying experiment were fitted into three (3) models (Page model, Henderson model and Lewis model) to predict the drying rate and to determine the best thin layer dryer suitable for drying Yam (dioscorea spp) slices.

\section{MATERIALS AND METHODS \\ 3.1 Materials} follows:

Materials used for this research work are as

\subsubsection{Knife}

This is a sharp blade with a handle used for cutting or as a weapon.

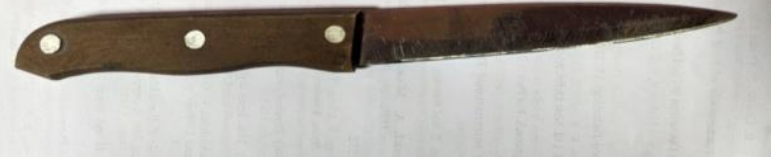

Plate-1: Knife

\subsubsection{Vernier Calliper}

A type of sliding device for measuring the external and internal dimensions of objects using the Vernier scale for improved precision. It is a metal device used for measuring the thickness between two surfaces, especially for small or precise measurements.

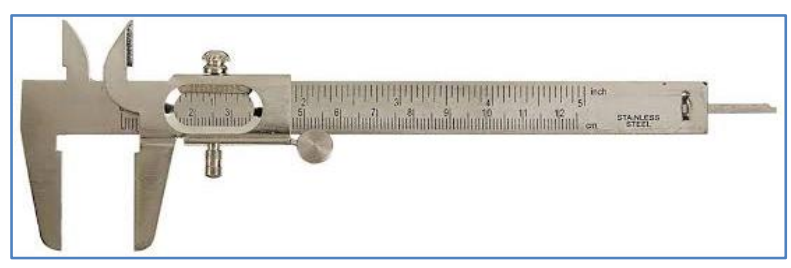

Plate-2: Vernier calliper

\subsubsection{Laboratory Type Digit Balance}

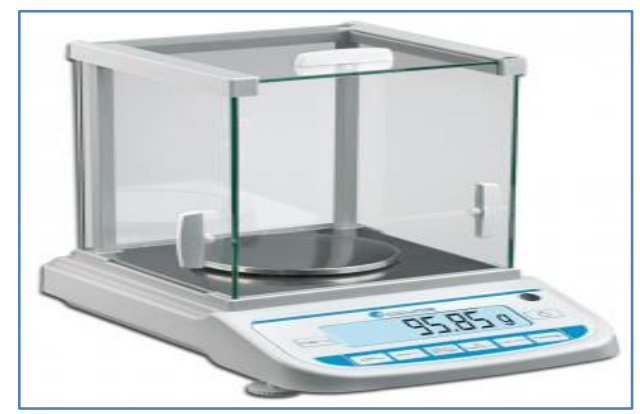

Plate-3: laboratory type digit balance

\subsubsection{Electric Oven}

The oven dryer is designed to remove moisture from the oven chamber so as to dry the samples as quick as possible. The drying oven process introduces fresh dry air to the chamber and expels the warm moist aur simulataneously allowing to rapidly dry the samples. An oven dryer provides high-performance drying and heating. The samples are dried for a defined period of time at constant temperature. The moisture content is determined by weighing the sample before and after drying.

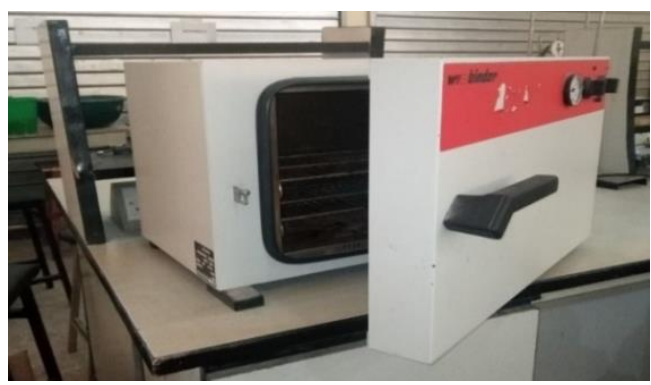

Plate-4: Electric oven 
Egbe EW; Saudi J Eng Technol, Jan, 2022; 7(1): 1-10

3.1.5 Tubers of Yam

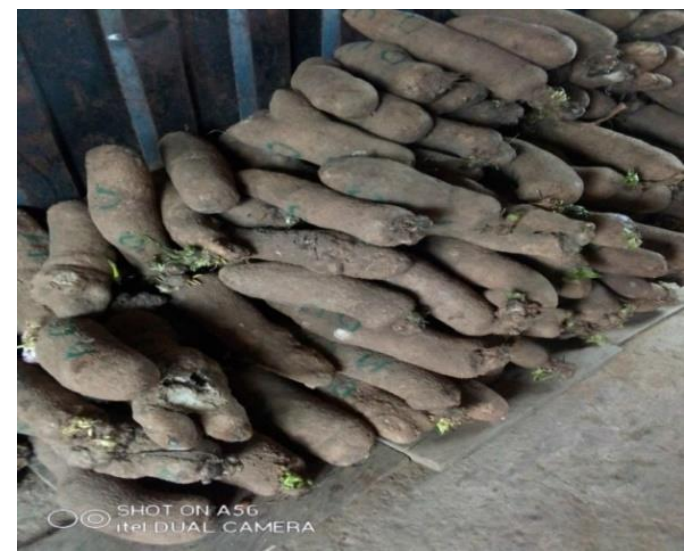

Plate-5: Tubers of yam

\subsubsection{BUCKET WITH LID}

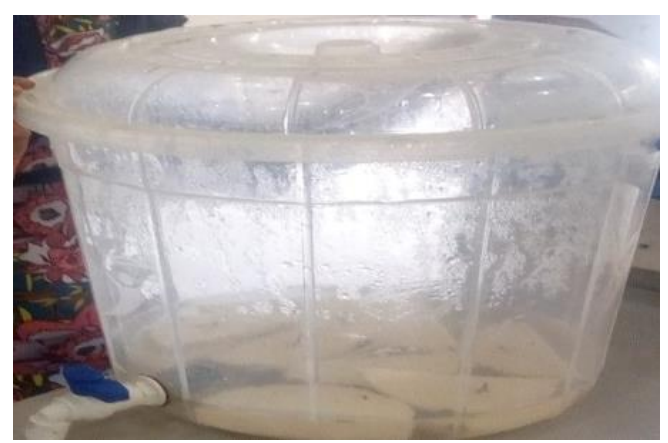

Plate-6: Bucket containing yam slices used for the Blanching

\subsection{METHODS}

An average size of dioscorea spp (yam) was obtained from a local market at Ondewari community in Southern Ijaw LGA, Bayelsa State, Nigeria. It was taken to the processing laboratory of the department of agricultural and environmental engineering, Niger Delta University, Bayelsa State Nigeria, located from Latitude $4^{\circ} 51^{\prime} \mathrm{N}$ to $5^{\circ} 02^{\prime} \mathrm{N}$, and from longitude $6^{\circ} .04^{\prime} \mathrm{E}$ to $6^{\circ} 17^{\prime} \mathrm{E}$ see plate 7 . The yam was first washed with clean water and peeled manually with stainless knife plate 1 . The yam slices blanched by soaking in boiled water for about $100^{\circ} \mathrm{C}$ for 5 -minutes interval as a means of pretreatment before the drying experiment took place see plate 6. Blanching is a means whereby women in Bayelsa state, south-south part of Nigeria used for the production of yam flour for retail or wholesales which enhances the drying process. Drying of pre-treatment yam slice (blanched) and (unblanched) yam slices were investigated out of the varying temperatures of 60,70 , and $80^{\circ} \mathrm{C}$ levels. The yam was sliced into $1.0 \mathrm{~mm}$, $1.5 \mathrm{~mm}$ and $2 \mathrm{~mm}$ slice thicknesses using vanier caliper see plate 2 in other to investigated the effect of temperature on yam slices. The different slices were weights before drying, during drying and after drying and were measured using electronic weighing balance see plate 3. Moisture reduction or loss was measured at every $30 \mathrm{mins}$ interval during the drying procedure to determine the drying curve. The processes was done repeatedly until there was no significant reduction or significant changes in the moisture content of the yam slices as the temperature increases. The moisture ratio of the yam slices was calculated using equation 1 below. (Aremu et al., 2013 and Fawoume et al., 2019).

$$
\mathrm{MR}=\frac{m-M_{e}}{M_{0}-M_{e}}
$$

Where me is equation equilibrium moisture content (EMC), $\mathrm{kgH}_{2} \mathrm{O}^{/ \mathrm{Kg}}$ solid, $\mathrm{M}_{0}$ is initial moisture content, $\mathrm{KgH}_{2} \mathrm{O}^{\mathrm{kg}}$ solid and $\mathrm{M}$ is as previously defined.

And from equation (2), if values of me are small in relation to values of $\mathrm{M}$ and $\mathrm{M}_{0}$ (assumed to be zero) in (Burubai, 2015; Roberts et al., 2008), then the equation would reduce to;

$$
\begin{aligned}
& \mathrm{MR}=\frac{M}{M_{0}} \\
& \mathrm{MR}=\frac{M-M_{e}}{M_{0}-M_{e}}=\frac{6}{\varepsilon_{1}} \exp ^{-\varepsilon_{1}\left(\frac{D_{e} t}{R_{c}{ }^{2}}\right)}
\end{aligned}
$$

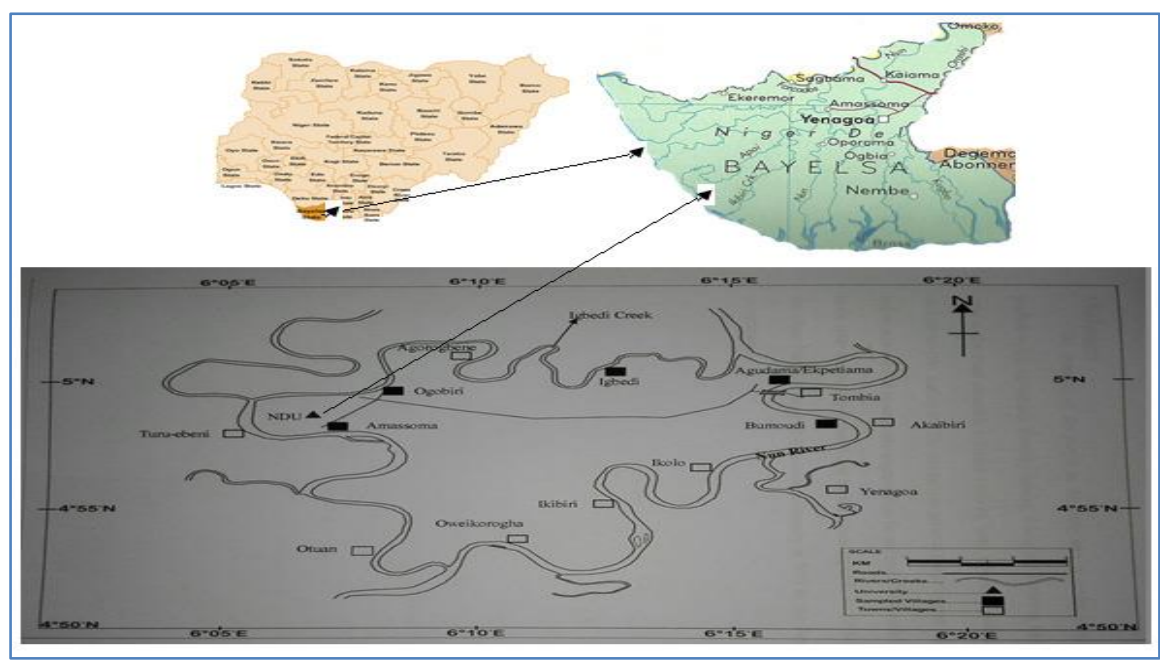

Plate-7: The MAP of Wilberforce Island, Nigeria 


\section{Thin-layer Drying Models}

The use of mathematical models in estimating the behaviour of agricultural and other bio-materials during drying is common in technological literature. Several of such thin-layer models exist but only three (the Lewis, the page and Henderson models respectively) are selected for validation in this work. From equation (3), taking $\mathrm{n}=1$ and further simplifying would bring about the thin layer drying equation of the Lewis model.

$$
\begin{aligned}
& \text { MR }=\exp ^{-\mathrm{kt}} \\
& \text { The Henderson model } \\
& \text { MR }=\operatorname{Aexp}^{-\mathrm{kt}} \\
& \text { And when } \mathrm{n}>1 \text {, the page model } \\
& \text { MR }=\exp ^{-\mathrm{ktn}} \\
& \text { Equation }(4) \text { can further simplify as } \\
& \text { In }(\mathrm{MR})=\text { In }(\mathrm{k})-\mathrm{kt} \\
& \text { Or } \quad \operatorname{In}\left(\frac{M}{M_{0}}\right)=\text { In }(\mathrm{k})-\mathrm{kt}
\end{aligned}
$$

Wherein $\mathrm{k}$ is seen as the rate constant and $\mathrm{a}, \mathrm{b}$, $\mathrm{n}$ are model coefficients. Then the plot of moisture ratio on natural logarithm axis against drying time of eq. (6), the intercept, In $(\mathrm{k})$ on the moisture ratio axis and slope, $-\mathrm{kt}$.

\subsection{STATISTICS FOR GOODNESS OF FIT}

Thin layer models can normally be evaluated and the quality of fit compared using certain statistical indicators such as coefficient of determination $\mathrm{R}^{2}$; the non-parametric reduced chi-square, $\mathrm{X}^{2}$, and the root mean square error, RMSE. The usual criteria is that an acceptable goodness of fit is said to have occurred in describing the drying curve of a given model if $\mathrm{R}^{2}$ value of the values of other indicators, $\mathrm{X}^{2}$, RMSE, are low. In this work, the experimental drying data of the samples obtained at different temperatures were used to fit into the three commonly used thin layer drying models. The goodness of fit of the selected mathematical models to the experimental data was evaluated using the given criteria (Maydeu et al., 2010; Wang et al., 2006). The statistical parameters used as the indicators were calculated as follows (Ndukwe et al., 2010), (Burubai, 2015).

\subsubsection{Coefficient of Determination, $\mathbf{R}^{2}$}

It is used in the context of statistical models whose main purpose is the prediction of future outcome on the basis of other related information. The coefficient of determination is not likely to be 0 or 1 but rather somewhere in between these limits. The closer it is to 1 , the greater relationship it becomes with the experimental and predicted values (Neter et al., 1990).

$\mathrm{R}^{2}=1-\left[\sum_{i=1}^{n}\left(M R_{\text {pre }, i}-M R_{\text {exp }, i}\right)^{2}\right]$

\subsubsection{Reduced Chi-square, $\mathrm{X}^{2}$}

The non-parametric reduced chi-square, is the mean square of the deviations between experimental and predicted values for the models and used to evaluate the fitting agreement of each model. The lower the values of $\mathrm{X}^{2}$ the better the goodness of the fit (Yang et al., 2007).

$$
\mathrm{X}^{2} \quad=\frac{\sum_{i=1}^{n}\left(M R_{\text {pre }, i}-M R_{\text {exp }, i}\right)^{2}}{n-k}
$$

\subsubsection{RMSE}

The root mean square error (RMSE) is required to reach zero. The statistical parameters used as the indicators were calculated as follows (Ndukwu et al., 2010), (Burubai, 2015).

$$
\mathrm{RMSE}=\sqrt{\frac{\sum_{i=1}^{n}\left(M R_{\text {pre }, i}-M R_{\exp , i}\right)^{2}}{n}}
$$

Where; $M R_{\text {pre. }}=$ predicted moisture ratio, $M R_{\text {exp. }}=$ experimental moisture ratio, $\mathrm{n}=$ number of observations and $\mathrm{k}=$ no. of constant.

\subsection{RESULTS AND DISCUSSIONS}

\subsection{CHARACTERIZING DRYING KINETICS}

Figure 1 and 2 are plots of moisture ratio of the pre-treated and untreated samples against drying time for the chosen temperature levels i.e $60^{\circ} \mathrm{C}, 70^{\circ} \mathrm{C}, 80^{\circ} \mathrm{C}$ while figures 3 and 4 shows the moisture ratio obtained for the logarithmic form [In (MR)] plotted as a function of drying time. The moisture ratios are all given in wet basis (wb). The plots show an initial accelerated moisture loss in drying due to quick diffusion and evaporation of free water. Drying however, became slower at the later stages of drying time, even with increasing temperatures. The sharp drop seen in the drying curves (figure 3 and 4) shows that removal of moisture from the pre-treated and untreated yam slices decreased as time increased. This is typical of such animal-muscled bio-materials with high level of constituent fats/oil and protein causing less water activity even with increase in drying temperature as investigated by (Zibokere and Egbe, 2021) on fresh water clawed lobster, (jain and pathare, 2007; Burubai and Bratua, 2016). This means that lesser water is available for evaporation at the surface of the samples; thus, drying rate is seen to decrease with time exemplifying a falling ratee drying proceeding without the feature of case-hardening even on the high ranges. This agrees with works on the thin layer drying of red pepper (Akpinar et al., 2003), tomatoes (Kross et al., 2004), plantain (Satimehin and Alabi, 2005), salted catfish fillets (Sankat and Mujalfar, 2006), yoghurt (Hayaloglu et al., 2007),hull-less seed pumpkin (Sacilik, 2007), fresh fish (Kilic, 2009), bitter cola (Ehiem and Simonyan, 2011), bananas (Ganesapillai et 
Egbe EW; Saudi J Eng Technol, Jan, 2022; 7(1): 1-10

al., 2011), pumpkin seeds (Jittanit, 2011), fresh tilapia fish (Zhiqiang et al., 2013) and clam (Burubai, 2015).

The effect of temperature on slice thicknesses on pre-treated and untreated yam slices was also investigated by comparing the drying curve at different temperature as presented in figure 1and 2. Moisture content of the yam slices reduces as the drying increases for all the slice thicknesses in both pre-treated and untreated yam slice. It was also observed that moisture loses as the dying progressed without no distinct constant rate period. The smaller the slice thicknesses for both pre-treated and untreated, the faster the dehydration process and the larger the thickness for the both samples the more time required for complete dehydration. This could be attributed to the different in the surface area that are exposed to heated air at a given volume of the product to the distance that moisture in the yam slice travel from the core to the slice reaching the surface where it could be easily evaporated. Similar results have been reported for mango (Aremu et al., 2013), Quercus fruits (Tahmasebi et al., 2011), kiwi fruit (Mohammadi et al., 2008). It was also discovered during the drying process that the drying rate of blanched yam slices was higher than the drying rate of fresh yam slice (untreated) for all the slice thicknesses investigated. Blanching resulted increased moisture content in yam slice and subsequently increased the quantity of free moisture that can be evaporated easily from the yam slice. Similar investigation has been reported by pre-treated cassava chip (Tunde-Akintunde and Afon 2010), pre-treated cocoyam (Oyefeso and Raji 2020), leek slices (Doymaz, 2008), and pumpkin slices (Limpaibron 2011).

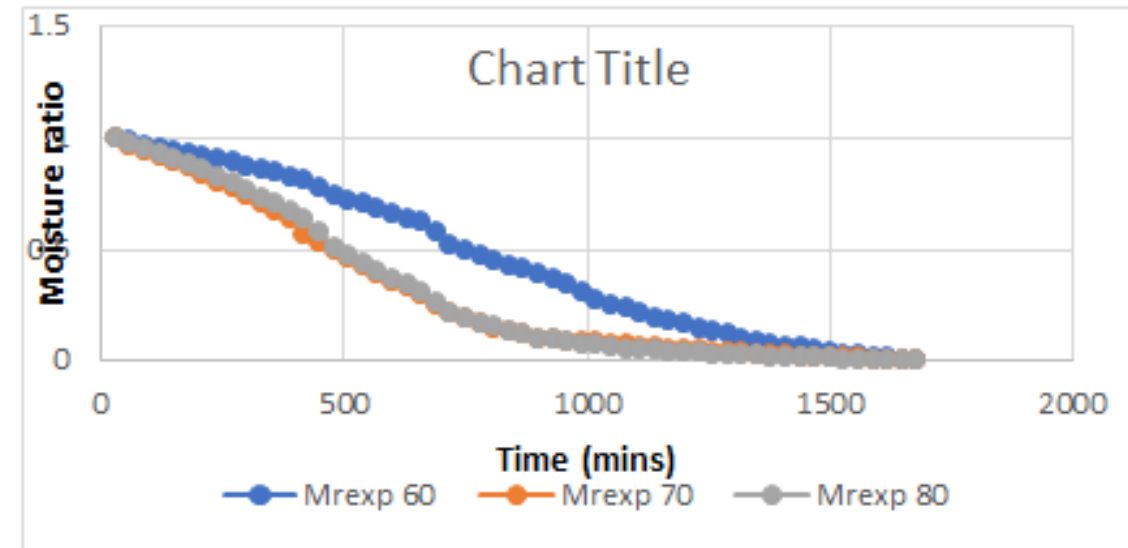

Fig-1: Graph of moisture ratio versus drying time of pre-treated Yam slices at different temperature

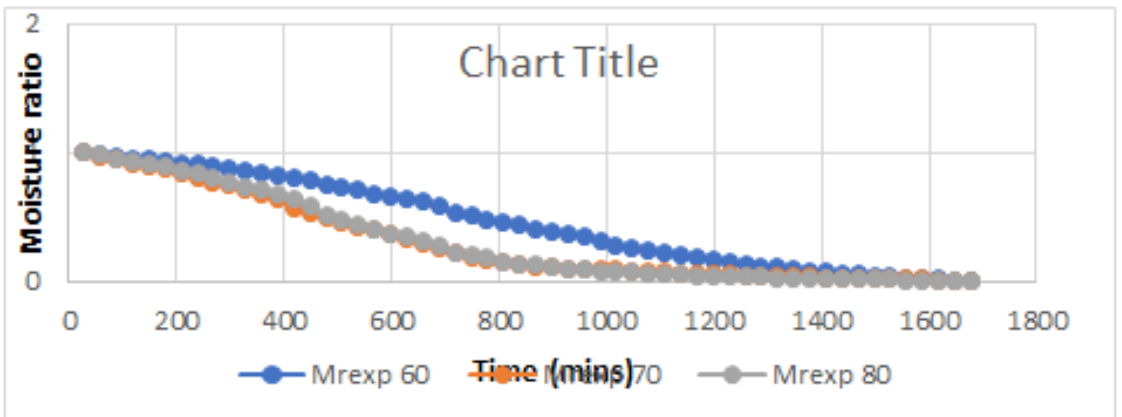

Fig-2: Graph of moisture ratio versus drying time of Untreated Yam slices at different temperature

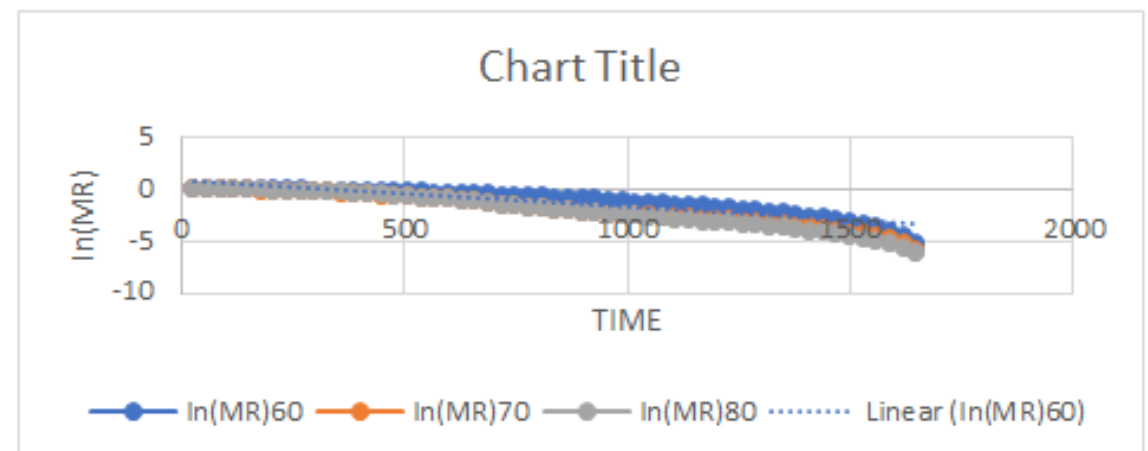

Fig-3: Graph of Drying curves of Logarithmic moisture ratio vs drying time for pre-treated yam slices 


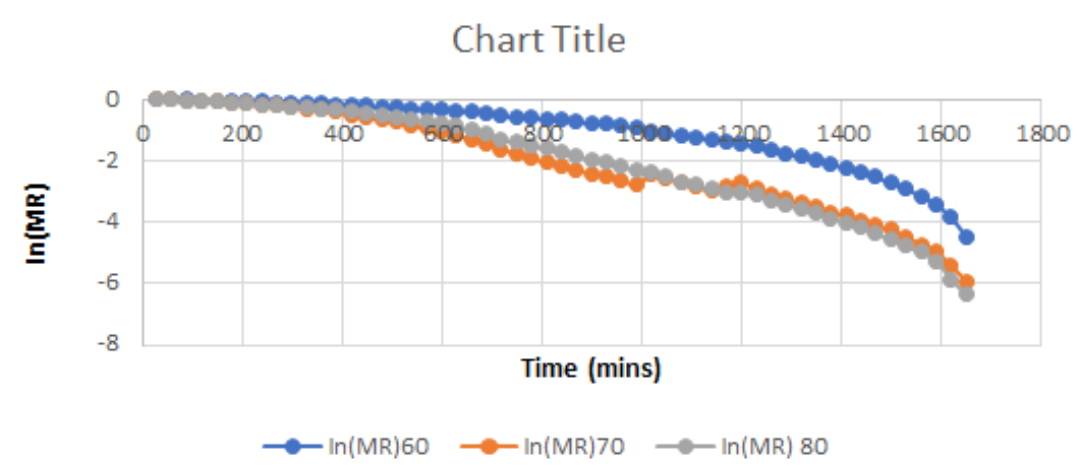

Fig-4: Graph of drying curves of Logarithmic moisture ratio vs drying time for pre-treated yam slices

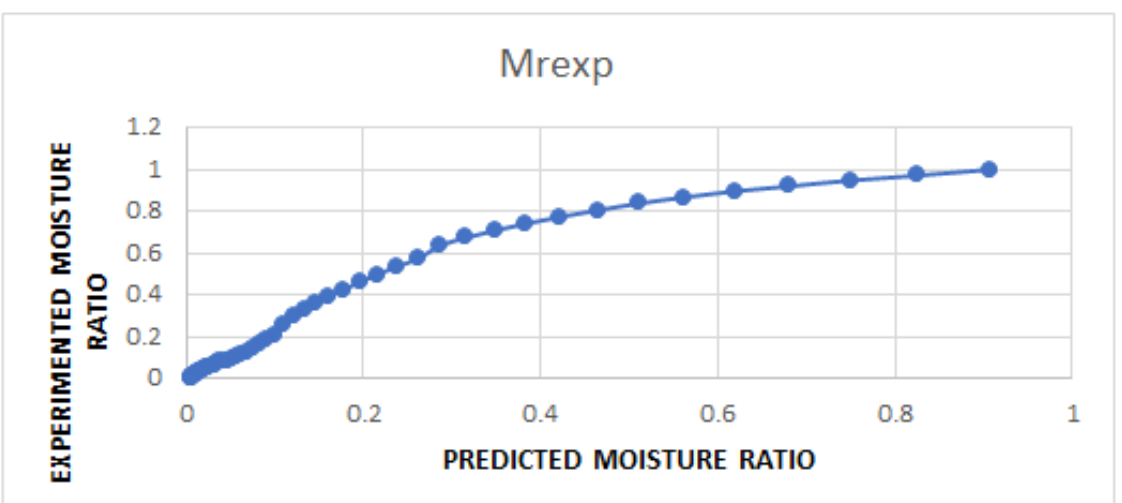

Fig-5: Graph showing the relationship between Experimented Moisture Ratio and Lewis Moisture Ratio Prediction at $70^{\circ} \mathrm{C}$ for pre-treated yam slices

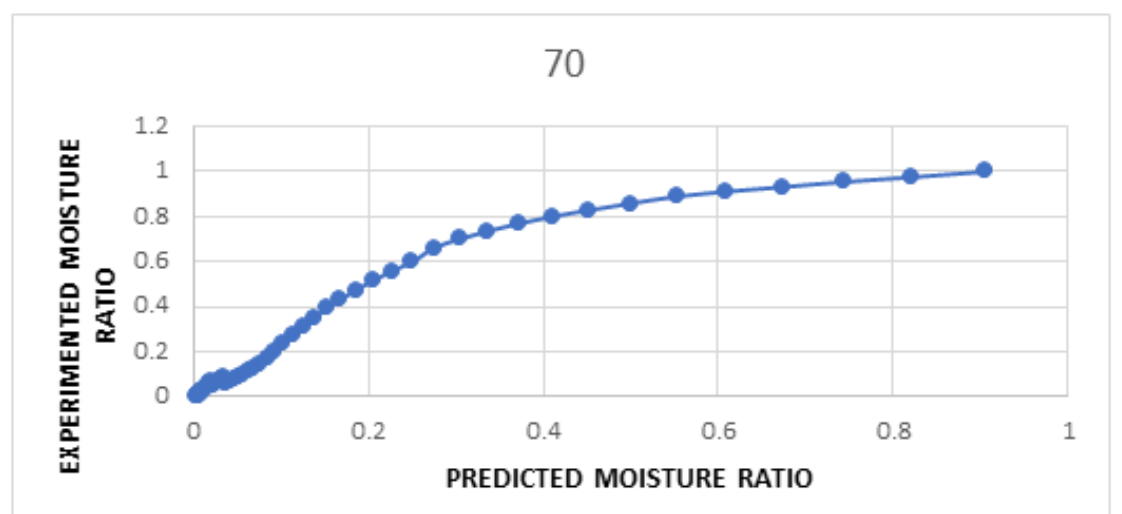

Fig-6: Graph showing the relationship between Experimented Moisture Ratio and Lewis Moisture Ratio Prediction at $\mathbf{7 0}^{\circ} \mathrm{C}$ for Untreated yam slices

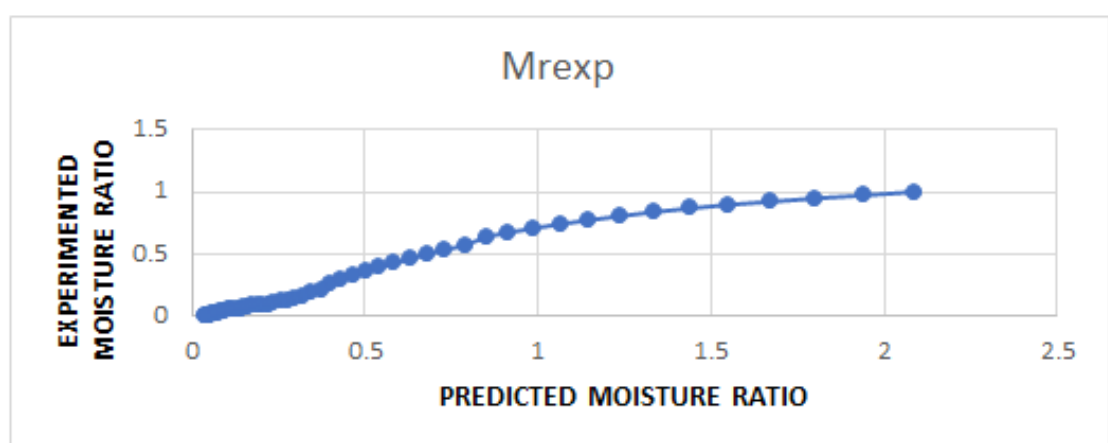

Fig-7: Graph showing the relationship between Experimented Moisture Ratio and Henderson Moisture Ratio Prediction at $7^{\circ} \mathrm{C}$ for pre-treated yam slices 


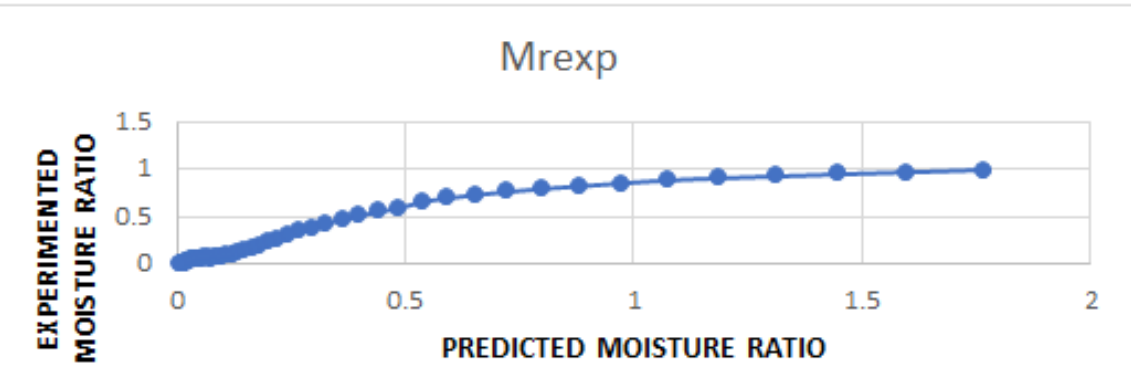

Fig-8: Graph showing the relationship between Experimented Moisture Ratio and Henderson Moisture Ratio Prediction at $\mathrm{80}^{\circ} \mathrm{C}$ for Untreated yam slices

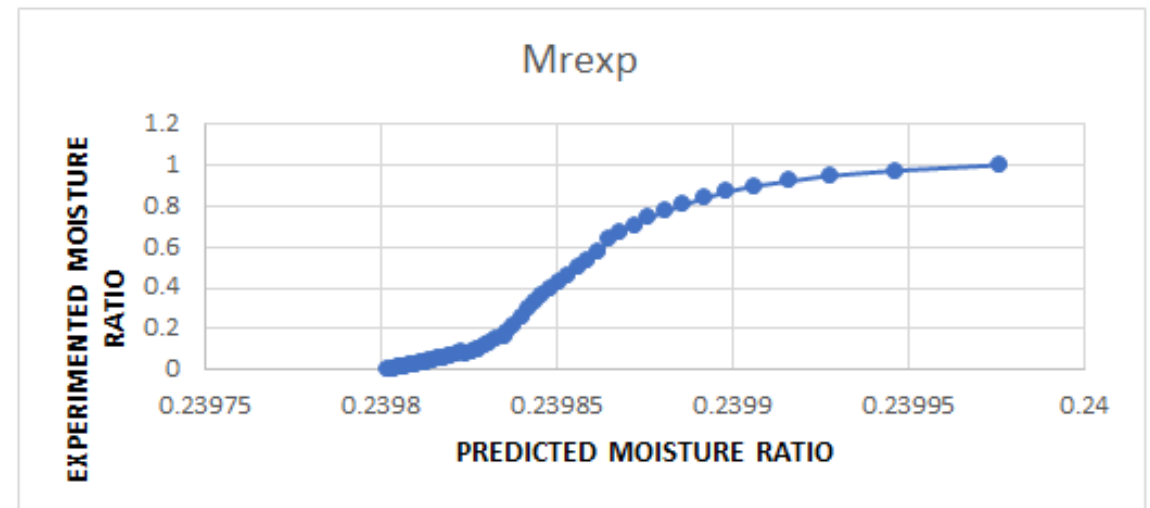

Fig-9: Graph showing the relationship between Experimented Moisture ratio and Page Model Moisture Ratio Prediction at $60^{\circ} \mathrm{C}$ for Pre-treated yam slices

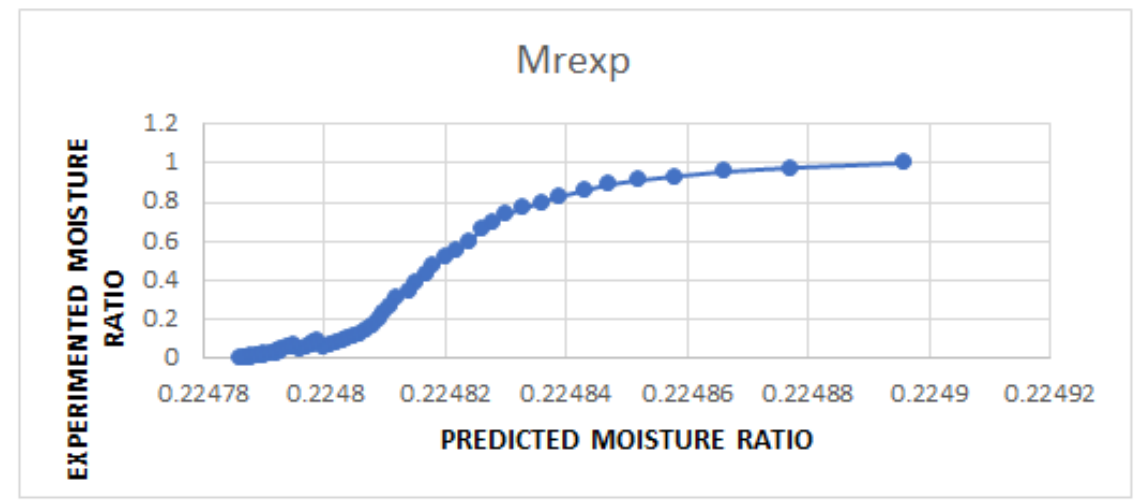

Fig-10: Graph showing the relationship between Experimented Moisture ratio and Page Model Moisture Ratio Prediction at $60^{\circ} \mathrm{C}$ for Untreated yam slices

\subsection{Fitting experimental data into thin layer drying models}

Estimating of the drying behaviour of the samples was done by fitting into the thin layer drying models of Lewis, Henderson and Pabis for the range. The fitting was done to enable selection of model that would best represent the drying behaviour of the specimens on thin layers. Table 1 presents the coefficient of determination, reduced chi square, and reduced mean square error values used to validate the fitting process statistically. Fitting constants were first obtained through a non-linear least square statistical analysis (SPP, 1996) using data from the experiments fitted into fick's diffusion equation. $\mathrm{R}^{2}$ values for the range of drying temperatures applied in this work were used as main criteria for the determination of acceptable thin layer drying model applicable for describing the drying data for the specimens. In table $1 \mathrm{R}^{2}$ values ranged from $0.912090-0.984462$ (pre-treated) and $0.947496-0.982675$ (untreated) for Lewis model, 0.996625-0.998228 (pre-treated) and 0.994750 0.998897 (untreated) for Henderson, 0.940210 0.997329 (pre-treated) and 0.938921-0.995356 (untreated) for page model with rather low RMSE values ranging from0.031620- 0.016657 (pre-treated) and $0.030334-0.017589$ (untreated) for Lewis model; $0.00773-0.005247$ (pre-treated) and 0.009682 0.004439 (untreated) for Henderson model; 0.032675 0.006907 (pre-treated) and 0.033026 0.009107 (untreated) for page model over the range of drying temperatures applied. The respective $\mathrm{X}^{2}$ values ranging from $0.031620-0.016657$ (pre-treated) and 
Egbe EW; Saudi J Eng Technol, Jan, 2022; 7(1): 1-10

$0.030334-0.017589$ (untreated) for lewis model; $0.007763-0.005247$ (pre-treated) and $0.009682-$ 0.004439 (untreated) for Henderson model; 0.032675 0.006907 (pre-treated) and $0.033026-0.009107$ (untreated) for page model (approximately $=0$ ), with experimental data values banded or clustered along the straight line of the plot. Henderson model gave a better goodness of fitness than the others. Thus, the Henderson was adjudged reasonably acceptable for estimating the drying characteristics of Dioscorea spp. It was observed during the experimentation process that, the pre-treated yam slices for the different temperature levels dried faster than the untreated yam slices.

Table-4.1: Statistical Parameters of Pre-treated and Untreated Yam sizes

\begin{tabular}{|c|c|c|c|c|c|c|c|}
\hline MODEL & $\begin{array}{l}\text { TEMP } \\
(\circ \mathrm{C})\end{array}$ & $\mathbf{R}^{2}$ & $\mathbf{X}^{2}$ & RMSE & $\mathbf{K}$ & $\mathbf{a}$ & $\mathbf{N}$ \\
\hline \multirow{8}{*}{ LEWIS } & \multicolumn{7}{|c|}{ PRE-TREATED } \\
\hline & 60 & 0.912090 & 0.0016000000 & 0.039620 & 0.0019 & & \\
\hline & 70 & 0.984462 & 0.0002830000 & 0.016657 & 0.0032 & & \\
\hline & 80 & 0.978815 & 0.0003850000 & 0.019450 & 0.0035 & & \\
\hline & \multicolumn{7}{|c|}{ UNTREATED } \\
\hline & 60 & 0.947496 & 0.0009370000 & 0.030334 & 0.0021 & & \\
\hline & 70 & 0.982675 & 0.0003150000 & 0.017589 & 0.0033 & & \\
\hline & 80 & 0.969877 & 0.0005480000 & 0.023193 & 0.0035 & & \\
\hline \multirow[b]{8}{*}{ HENDERSON } & \multicolumn{7}{|c|}{ PRE-TREATED } \\
\hline & 60 & 0.997154 & 0.0000527000 & 0.005247 & 0.0019 & 2.253084 & \\
\hline & 70 & 0.998228 & 0.0000328100 & 0.005625 & 0.0032 & 1.928804 & \\
\hline & 80 & 0.996625 & 0.0000624900 & 0.007763 & 0.0035 & 2.243865 & \\
\hline & \multicolumn{7}{|c|}{ UNTREATED } \\
\hline & 60 & 0.998391 & 0.0000297900 & 0.005361 & 0.0021 & 2.002300 & \\
\hline & 70 & 0.998897 & 0.0000204300 & 0.004439 & 0.0033 & 1.947604 & \\
\hline & 80 & 0.994750 & 0.0000972000 & 0.009682 & 0.0035 & 2.530457 & \\
\hline \multirow[b]{8}{*}{ PAGE } & \multicolumn{7}{|c|}{ PRE-TREATED } \\
\hline & 60 & 0.940210 & 0.0011072060 & 0.032675 & 1.5541 & & 0.000029 \\
\hline & 70 & 0.997329 & 0.0000494700 & 0.006907 & 1.4266 & & 0.000927 \\
\hline & 80 & 0.993449 & 0.0001210000 & 0.010816 & 1.5329 & & 0.000063 \\
\hline & \multicolumn{7}{|c|}{ UNTREATED } \\
\hline & 60 & 0.938921 & 0.0011310990 & 0.033026 & 0.9505 & & 0.001110 \\
\hline & 70 & 0.995356 & 0.0000860000 & 0.009107 & 1.4917 & & 0.000081 \\
\hline & 80 & 0.983940 & 0.0002970000 & 0.016935 & 1.5706 & & 0.000044 \\
\hline
\end{tabular}

\subsection{CONCLUSSION AND RECOMMENDATION}

An investigation on the effects of temperature on dehydration kinetics of pre-treated and untreated yam slices was conducted to characterize the drying kinetics of yam (Dioscorea spp) on thin layers. Drying was observed to follow the falling rate period in line with several literature reports on other biological materials. Experimental data were fitted to selected three thin layer models to explore the best for predicting the drying kinetics of the pre-treated and untreated yam slices. Blanched yam slices had higher drying rates than the fresh yam slices and reduced slice thickness helped to reduce the drying period. This shows that the drying process can be described principally by the diffusion mechanism. Combination of thin slices of yam with some level of pre-treatment such as blanching is recommended for faster moisture removal from the yam. This work can be useful in the design and development of drying equipment for the preservation of yams. However, limited the selection of thin-layer drying models to only three. An attempt could be made to extend the selection base beyond the limit applied in this work to obtain higher degree of freedom on the statistical exactness of the drying data for improved drying system design.

\section{REFERENCES}

- Akpinar, E. K., Bicer, Y., \& Yildiz, C. (2003). Thin layer drying of red pepper. Journal of food engineering, 59(1), 99-104.

- Burubai, W. (2015). "Thin layer drying kinetics of fresh-water clam (tridacna maxima)," Umudike journal of Engineering and Technology, 1(1), 7990.

- Burubai, W., \& Bratua, I. (2016). Drying kinetics of pre-osmosed water frog (Diocroglaglossus occipitalis). Nigerian journal of technology (NIJOTECH), 35(4), 935 - 939).

- Calverly. (1998). "Storage and processing roots and tubers in the tropics". Food and agriculture association of the United Nations. Centre for Agriculture and biosciences international (CBI), 2016.

- Domínguez-Niño, A., Lucho-Gómez, A. M., Pilatowsky-Figueroa, I., López-Vidaña, E. C., Castillo-Téllez, B., \& García-Valladares, O. 
Egbe EW; Saudi J Eng Technol, Jan, 2022; 7(1): 1-10

(2020). Experimental study of the dehydration kinetics of chicken breast meat and its influence on the physicochemical properties. CyTA-Journal of Food, 18(1), 508-517.

- Doymaz, I. (2008). Influence of blanching and slice thickness on drying characteristics of leek slices. Chemical Engineering and Processing Process Intensification, 47(1); 41-47.

- Egbe, E. W. (2021). Proximate Composition of Okpokuru (Oryctes Rhinoceros) and Red Palm Weevil Larva (Rhynchophorus Ferrugineus). Sch J Eng Tech, 11, 199-204.

- $\quad$ Ehiem J.C., \& Simonyan, K.J. (2011). Thin layer drying characteristics of bitter kola. Proceedings of the Nigerian institution of Agricultural Engineers, 32, $384-390$.

- Fawohunre, A. J., B. A. Adewumi, O. U. Dairo, and O. P. Sobukola. (2019). Fitting model for the thin layer drying of plantain (Musa acuminata). American Journal of Engineering Research, 8(8); 160-166.

- Ganesapillai, M., Regpathi, L., \& Murugesan, T. (2011). Modelling of thin-layer drying of banana under microwave, convective and combined microwave - convective process. Chemical products and modelling, 6(1), $1-10$.

- Guan, Z., Wang, X., Li, M., \& Jiang, X. (2013). Mathematical modelling on hot air drying of thin layer fresh tilapia fillets. Polish journal of food and nutrition sciences, 63(1).

- Hayaloglu, A.A., Karabulut, I., Alpaslan, M., \& Kelbaliyev, G. (2007). Mathematical modelling of drying characteristics of strained yoghurt in a convective type 308 tray-dryer. Journal of food Engineering, 78, 109-117.

- Horuz, E., Bozkurt, H., Karatas, H., \& Maskan, M. (2020). Microwave-conventional drying characteristics of red pepper: modeling, temperature profile, diffusivity and activation energy. Journal of Agricultural Science and Technology, 22(2), 425-437.

- Jain, D., \& Pathare, P. B. (2007). Study the drying kinetics of open sun drying of fish. Journal of food Engineering, 78(4), 1315-1319.

- Jittanit, W. (2011). Kinetics and temperatures dependent moisture diffusivity of pumpkin seeds during drying. Kasetsart journal (Natural science). $45,147-158$.

- $\quad$ Kabiru, A. A., Joshua, A. A., \& Raji, A. O. (2013). Effect of slice thickness and temperature on the drying kinetics of mango (Mangifera indica). International Journal of Research and Review in Applied Sciences, 15(1), 41-50.

- Kilic, A. (2009). Low temperature and high velocity (LTHN) application in drying: characteristic and effect on fish quality. Journal of food Engineering, 91, 173 - 182.

- Kross, R. K., Mata, M. E. R. M. C., Duarte, M. E. M., \& Junior, V. S. (2004). Drying Kinetics of
Tomatoes (Lycopersicon esculentum L.), Submitted to a Previous Osmotic Treatment. In 11th International Drying Symposium IDS (pp. 2133-2140)

- Limpaiboon, K. (2011). Effects of temperature and slice thickness on drying kinetics of pumpkin slices. Walailak Journal of Science and Technology (WJST), 8(2), 159-166.

- Maydeu-Olivares, A., \& Garca-Forero, C. (2010). Goodness-of-fit testing. International Encyclopaedia of Education 7:190-196.

- Maydeu-Olivares, A., \& Garca-Forero, C. (2010). Goodness-of-fit testing. International Encyclopaedia of Education 7:190-196.

- Mohammadi, A., Rafiee, S., Keyhani, A., \& Emam-Djomeh, Z. (2008). Estimation of Thinlayer Drying Characteristics of Kiwifruit (cv. Hayward) with use of Page's Model. AmericanEurasian J. Agric. Environ. Sci, 3, 802-805.

- Ndukwe, M. C., Ogunlowo, A.S., \& Olukunle, O.J. (2010). Cocoa bean (Theoboroma cacao) drying kinetics. Chilean journal of Applied Agriculture, 70(4), 633-639.

- $\quad$ Neter, J., Wesserman, W., \& Kutner, M. H. (1990). Applied Linear Statistical Models. Regression Analysis of Variance and Experimental Designs. Ricrd D. Irwin Inc., USA

- Ojediran, J. O., Okonkwo, C. E., Adeyi, A. J., Adeyi, O., Olaniran, A. F., George, N. E., \& Olayanju, A. T. (2020). Drying characteristics of yam slices (Dioscorea rotundata) in a convective hot air dryer: Application of ANFIS in the prediction of drying kinetics. Heliyon, 6(3), e03555.

- Roberts, J.S, Kidd, D.R., \& padilla-zakar, O. (2008). Drying kinetics of grape seeds. journal of food engineering, 89; 460:465.

- Sacilik, K. (2007). Effect of drying methods on thin-layer drying characteristics of hull-less seed pumpkin. Journal of food Engineering. 79, 23-30.

- Sankat, C.K., \& Mujaffar, S. (2006). Modelling of the drying behaviour of salted catfish fillets. Proceedings of the $15^{\text {th }}$ international drying symposium (IDS 2006), Budapest Hungary, 20-23 August.

- Satimehin, A.A., \& Alabi, T.O. (2005). Drying kinetics of plantain (musa paradisiaca) chips. Proceedings of the Nigerian Institute of Agricultural Engineers (NIAE). 27, 289-294.

- Sharma, G., Prasad, S. (2001). Drying of garlic (Allium Sativum) cloves by microwave-hot air combination. Journal of food Engineering, 50; 99 105

- Tahmasebi, M., T. T. Hashjin, M. H. Khoshtaghaza, and A. M. Nikbakht. (2011). Evaluation of thin-layer drying models for simulation of drying kinetics of quercus (Quercus persica and Quercus libani). Journal of Agriculture Science and Technology, 13(2); 155-163. 
- Tunde-Akintunde, T. Y., \& A. A. Afon. (2010). Modelling of hot- air drying of pre-treated cassava chips. CIGR E-Journal, 12(2); 34-41.

- Ukonze, J. A., \& Olaitan, S. O. (2010). Competency improvement needs of women in agriculture in processing cocoyam into flour and chips for food security in South Eastern Nigeria. African Journal of Teacher Education, 1(1); 149157.

- Vijaya, G.S., Raghavan, V. Orsat. (2010). Recent advances in drying of biomaterials for superior quality bioproducts. Asia-pacific Journal of chemical Engineering, 20

- Wang, Z., Sun, J., Liao, C. F., Zhao, G., \& Wujand, H.U.X. (2006). Mathematical modelling on hot air drying of thin layer apple pomace. Journal of food Engineering, 40: 39-46.
- Yang, C. Y., Fon, D. S., \& Lin, T. T. (2007). Simulation and validation of thin layer models for peanut drying. Drying technology, 25(9), 15151526.

- Zibokere ,D.S., \& Egbe, E.W. (2021). Thin Layer Drying Kinetics of Freshwater Clawed Lobster (Astacus astacus). Nigerian Journal of Technology, 40(2), 340-347

- Zibokere, D., \& Egbe, E. (2019). Thin-layer drying kinetics of palm weevil (rhynchophorus ferruguneus) larvae. Annals of Applied Science, 5(2), 40-46.

- Zogzas, N.P., Maroulis, Z.B., \& Marinos-Kouris, D. (1996). Moisture diffusivity data complication in foodstuffs. Drying technology, 14, 2225-2253. 